\title{
Servicescape dan Pengaruhnya Terhadap Kepuasan Pelanggan: Studi Pada Konsumen Eduplex Bandung
}

\author{
Azmi Mutia Ainun ${ }^{1 *}$ dan Maya Setiawardani \\ ${ }^{1}$ Jurusan Administrasi Niaga, Politeknik Negeri Bandung, Indonesia \\ ${ }^{2}$ Jurusan Administrasi Niaga, Politeknik Negeri Bandung, Indonesia
}

\begin{abstract}
:
Lifestyle communities are growing, have an impact on people's lives in fulfilling his needs. One of them, namely the need for food. To meet the needs of the food, people are more likely to go to a fast-food restaurant or Cafe. Specifically for the cafe, at this time many cafes are there in the city of Bandung stand not only to put forward products are sold, but also very attentive to the comfort of a given place.The purpose of this research is to know the servicescape and its effect on customer satisfaction at the Eduplex in Bandung.The sample in this study i.e. as many as 117 people respondents with the method of analysis used a classic assumption test, i.e. an analysis of descriptive statistics, correlation and simple linear regression, simple, the coefficient of determination and test hypotheses. The results showed that there is a very strong positive relationship between the servicescape with customer satisfaction. Servicescape also has a significant positive influence and contribute towards a large enough customer satisfaction Eduplex Bandung, Bandung Eduplex should then able to better maximize existing servicescape to maintain customer satisfaction customer.
\end{abstract}

Keywords: cafe, customer satisfaction, servicescape

\begin{abstract}
Abstrak:
Gaya hidup masyarakat yang semakin berkembang, berdampak pada kehidupan masyarakat dalam memenuhi kebutuhannya. Salah satunya, yaitu kebutuhan akan makanan. Untuk memenuhi kebutuhan makanan, orang lebih cenderung pergi ke restoran cepat saji atau Cafe. Khusus untuk warnet, saat ini banyak kafe yang ada di kota Bandung berdiri tidak hanya mengedepankan produk yang dijual, tetapi juga sangat memperhatikan kenyamanan tempat tertentu. Tujuan penelitian ini adalah untuk mengetahui servicescape dan pengaruhnya terhadap kepuasan pelanggan di Eduplex di Bandung. Sampel dalam penelitian ini yaitu sebanyak 117 orang responden dengan metode analisis menggunakan uji asumsi klasik, yaitu analisis statistik deskriptif, korelasi dan regresi linier sederhana, sederhana, koefisien determinasi dan uji hipotesis. Hasil penelitian menunjukkan bahwa ada hubungan positif yang sangat kuat antara servicescape dengan kepuasan pelanggan. Serviscape juga memiliki pengaruh positif yang signifikan dan berkontribusi terhadap kepuasan pelanggan yang cukup besar Eduplex Bandung, Bandung Eduplex kemudian harus dapat lebih memaksimalkan layanan yang ada kera untuk menjaga kepuasan pelanggan pelanggan.
\end{abstract}

Kata Kunci: kafe, kepuasan pelanggan, servicescape

Jurnal Riset Bisnis dan Investasi 


\section{Pendahuluan}

Perkembangan bisnis sangat terasa di beberapa kota besar yang ada di Indonesia khususnya Kota Bandung. Terbukti dengan maraknya destinasi wisata yang dapat di kunjungi oleh para wisatawan baik lokal maupun mancanegara. Mulai dari dari objek wisata alam, wisata sejarah, wisata berbelanja pakaian (factory outlet) bagi sebagian orang, dan yang paling menarik adalah wisata kuliner. Banyak tempat kuliner yang dapat dikunjungi di Kota Bandung mulai dari pedagang kuliner kecil atau pedagang kaki lima, restoran, foodcourt, dan juga kafe.

Khusus untuk kafe, pada saat ini banyak kafe-kafe yang ada di Kota Bandung berdiri tidak hanya mengedepankan produk yang dijual, tetapi juga sangat memperhatikan kenyamanan tempat yang diberikan. Keinginan pelanggan mulai tidak terpaku hanya pada produk yang dijual akan tetapi juga sangat memperhatikan pelayanan yang diberikan dan juga nuansa kenyamanan ketika berada di kafe. Kafe dengan suasana yang menyenangkan sangat dibutuhkan oleh masyarakat yang memiliki tingkat mobilitas yang tinggi di luar rumah. Pada akhirnya, kafe menjadi sebuah bisnis yang tak hanya menyediakan produk akan tetapi juga sebagai penyedia jasa.

Menurut Badan Pusat Statistik (BPS) Kota Bandung yang baru diperbarui pada tanggal 29 Agustus 2017, kuliner merupakan salah satu potensi sektor ekonomi kreatif yang dimiliki Kota Bandung. Berbagai jenis kuliner baru bermunculan di sepanjang tahun 2016. Selain itu, di sepanjang tahun 2016 banyak sekali event-event kuliner yang diselenggarakan di Kota Bandung. Pada tahun 2016, jumlah restoran atau rumah makan di Kota Bandung ada sebanyak 795 unit. Dari 795 unit tersebut terdiri dari 396 unit restoran (50\%), 372 unit rumah makan, 14 unit kafe (2\%), dan 13 unit bar (1\%). Berikut adalah grafik dari jenis-jenis kuliner yang ada di Kota Bandung

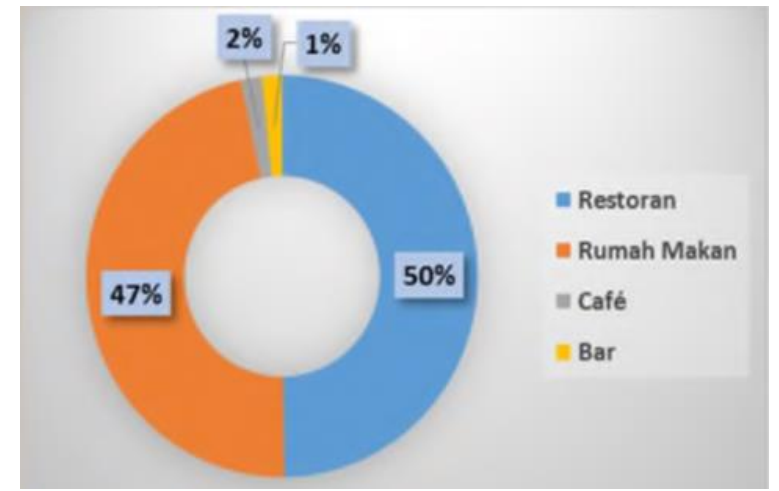

Gambar 1. Jumlah Restoran atau Rumah Makan di Kota Bandung

Gambar 1 menunjukkan bahwa Kota Bandung di dominasi oleh konsep rumah makan. Badan Pusat Statistik (BPS) Kota Bandung juga menyatakan bahwa terdapat lebih dari $60 \%$ pemilik kafe yang ada di Kota Bandung tidak mendaftarkan usahanya secara resmi, sehingga pada tahun 2016 jumlah kafe yang terdaftar hanya sebanyak 14 unit kafe. Dari 2\% kafe yang ada di Kota Bandung terdapat beberapa jenis konsep kafe yang di usung, salah satunya yaitu konsep kafe dan co-workingspace. Berikut adalah beberapa kafe dan co-workingscpace yang ada di Kota Bandung.

Tabel 1. Daftar Kafe dan Co-Workingspace di Kota Bandung

\begin{tabular}{|c|l|l|}
\hline No & \multicolumn{1}{|c|}{ Nama } & \multicolumn{1}{c|}{ Alamat } \\
\hline 1 & Eduplex & Jl. Ir. H. Djuanda 84, Bandung \\
\hline 2 & Ruangreka & Jl. Raden Patah 28, Bandung \\
\hline 3 & Bandung Digital Valley & Jl. Gegerkalong Hilir 47, Bandung \\
\hline 4 & Dilo & Jl. Banda nomor 40, Bandung \\
\hline 5 & Work@ & Jl. Tubagus Ismail XV no. 14A, Bandung \\
\hline 6 & Co\&Co & Jl. Dipatiukur 5, Bandung \\
\hline 7 & Freenovation Sidehouse & Jl. Bagusrangin 21 A, Bandung \\
\hline
\end{tabular}

Sumber: glints.com 
Dari tujuh kafe dan co-workingspace yang di sajikan di atas, yang paling menarik perhatian adalah Eduplex Bandung yang berada di urutan pertama. Eduplex Bandung merupakan kafe mengambil konsep bimbel kafe yang berada di Jalan Ir. H. Djuanda no.84, tepatnya di daerah Dago Bandung. Eduplex sendiri merupakan hasil dari pengembangan bimbel Edulab milik Oki Earlivan Sampurno yang awalnya dibuat sebagai tugas akhir perkuliahannya. Bimbel kafe yang berdiri tahun 2015 ini dirancang karena melihat peluang bisnis ketika belum adanya tempat khusus untuk belajar yang menyenangkan dan santai seperti halnya di kafe. Tidak hanya menyediakan tempat untuk belajar, Eduplex juga menyediakan tempat untuk bekerja atau co-workingspace. Sebagai penunjangnya, terdapat ruang conference room dan meeting room yang membutuhkan tempat diskusi yang lebih eksklusif.

Karena pada dasarnya adalah kafe, tidak semua wilayah Eduplex sifatnya berbayar seperti halnya co-workingspace. Banyak fasilitas yang dapat digunakan dalam kafe secara gratis. Konsep kafe yang nyaman membuat kalangan pelajar dan mahasiswa sudah cukup puas ketimbang harus menyewa ruangan dalam co-workingspace. Bagian kafe diperuntukkan untuk siapa saja yang datang yang sekedar ingin menikmati tempat. Jika di perhatikan, Eduplex sangat memperhatikan servicescape yang ada.

Servicescape adalah sebuah kata yang jarang sekali digunakan dalam mendefinisikan lingkungan fisik pelayanan. Walaupun jarang digunakan dalam kehidupan sehari-hari, tanpa sadar servicescape selalu mudah untuk dijumpai. Contohnya seperti denah sebuah tempat, kondisi lingkungan sekitar, suhu udara, intensitas cahaya, musik, tata letak, dan masih banyak lagi. Menurut Bitner (1992) servicescape adalah sebuah lingkungan fisik yang mencakup pelayanan yang ada pada suatu fasilitas interior maupun eksterior di dalamnya.

Berdasarkan hasil wawancara yang telah dilakukan kepada sebanyak 30 orang pelanggan Eduplex, kurang dari $50 \%$ pelanggan menyatakan bahwa mereka kurang puas dengan servicescape yang ada di Edupex Bandung. Lebih tepatnya lagi, sebanyak $37 \%$ pelanggan menyatakan bahwa lingkungan fisik yang disajikan oleh Eduplex Bandung kurang memuaskan karena berbagai macam alasan.

Servicescape dapat menjadi sebuah ketertarikan tersendiri bagi pelanggan dengan memperhatikan beberapa bagian yang ada. Bitner (1992) mengemukakan bahwa terdapat tiga dimensi yang menggambarkan servicescape yaitu ambient condition, spatial layout and functionality, dan signs, symbols, and artifacts. Jika, tiga dimensi tersebut dikelola dengan baik, maka pelanggan akan merasakan kepuasan.

Selanjutnya, jika dilihat hasil wawancara, $63 \%$ pelanggan merasa puas akan suasana yang diberikan oleh Eduplex. Eduplex sudah dapat memenuhi keinginan pelanggan yang menimbulkan kepuasan tersendiri. Kepuasan konsumen menurut Kotler (2009) adalah perasaan senang atau kecewa seseorang yang timbul karena membandingkan kinerja yang dipersepsikan produk (atau hasil) terhadap ekspektasi mereka. Artinya bahwa kepuasan adalah perasaan senang, puas individu karena antara harapan dan kenyataan dalam memakai dan pelayanan yang diberikan terpenuhi. Menurutnya terdapat tiga karakteristik yang mencerminkan kepuasan pelanggan yaitu repurchase, customer will recommend the product or service to others, dan customer never complain. Berdasarkan fenomena di atas, maka penulis merasa tertarik untuk melakukan penelitian tentang servicescape yang ada di Eduplex Bandung sebagai salah satu bentuk komunikasi untuk mengetahui bagaimana respon kepuasan pelanggan.

\section{Kajian Literatur}

\subsection{Servicescape}

Bitner (1992) menciptakan istilah "servicescape" untuk menunjukkan pengaturan fisik di mana pertukaran pasar dilakukan, disampaikan, dan dikonsumsi dalam layanan organisasi. Selain itu, Bitner mengkonseptualisasikan adanya tiga jenis rangsangan objektif (ambient condition), fisik (spatial layout and functionality), dan terukur yang merupakan layanan (sign, symbol, and artifacts). Bitner mengonsolidasikan rangsangan lingkungan ini menjadi tiga dimensi yaitu pada saat membangun model dasar psikologi lingkungan. Model Bitner ini menunjukkan bahwa terdapat penyeimbang antara respon pelanggan dan pegawai. Artinya, lingkungan jasa yang sama dapat memberikan dampak berbeda terhadap berbagai pelanggan, bergantung pada siapa pelanggan tersebut dan apa yang ia suka dan lebih bersifat subjektif. 
Menurut Hightower dan Shariat (2009:381) servicescape didefinisikan sebagai "the servicescape define here in as everything that is physically present around the consumer during their service encounter transcation" yang artinya segala sesuatu yang secara fisik hadir di sekitar konsumen selama pertemuan transaksi layanan jasa. Selain itu, menurut Zeithmal dan Bitner (2009) servicescape didefinisikan sebegai "Physical evidence as the service environment in which the service is delivered and in which the firm and customer interact, and any tangible commodities that facilitate performance or communication of the service" yang berarti bahwa servicescape adalah lingkungan dimana jasa disampaikan dan dimana perusahaan dan konsumennya berinteraksi, serta setiap komponen berwujud yang memfasilitasi penampilan atau komunikasi dari jasa. Menurutnya terdapat tiga dimensi dalam mengukur servicescape yaitu ambient component, design component, dan social component. Berdasarkan pengertian di atas dapat disimpulkan bahwa servicescape adalah tampilan fisik dalam suatu tempat yang dirancang sedemikian rupa untuk menarik atau mempengaruhi konsumen dan karyawan.

\subsection{Kepuasan Pelanggan}

Menurut Tjiptono dan Diana (2015:17) ada beberapa definisi mengenai kepuasan pelanggan. Pertama, jika dilihat dari segi definisi atau pengertian, ada dua tipe yang dominan. Kepuasan pelanggan dipandang sebagai sebuah outcome atau hasil yang didapatkan dari pengalaman menggunakan barang atau jasa spesifik atau bisa juga disebut dengan outcome-oriented approach. Kedua, dalam hal model konsep kepuasan pelanggan, terdapat dua model yang sering dijumpai yaitu model makro dan model mikro. Ketiga, kepuasan pelanggan juga dapat bersifat emosional dan juga resional atau penilaian kognitif. Keempat, kepuasan pelanggan juga dapat diartikan bermacam-macam dalam hal level spesifisitas (level of specificity).

Menurut Kotler dan Keller (2013) "Satisfaction is a person's feelings of pleasure or dissapointment that result from comparing a product's perceived performance or outcome to expectations. If the performance falls short of expectations, the outcome is dissatisfied. If it matches expectations, the customer is satisfied or delighted" atau dengan kata lain bahwa sebuah kepuasan akan dirasakan oleh seseorang yang ketika apa yang diharapkan oleh pelanggan sesuai dengan kinerja atau hasil yang mereka terima. Customer satisfaction juga perasaan senang atau kecewa yang dirasakan seseorang yang berasal dari perbandingan antara kesannya terhadap kinerja (hasil) suatu produk dan harapanharapannya, dengan kata lain kepuasan sebagai evaluasi paska konsumsi dimana suatu alternatif yang dipilih setidaknya memenuhi atau melebihi harapan.

Dalam konsep kepuasan pelanggan terdapat dua elemen yang mempengaruhi, yaitu harapan dan kinerja. Kinerja adalah persepsi konsumen terhadap apa yang diterima setelah mengkonsumsi produk. Harapan adalah perkiraan konsumen tentang apa yang akan diterima apabila ia mengkonsumsi produk (barang atau jasa) kepuasan pelanggan. Menurut Wakefield \& Blodgett (1996), kepuasan pelanggan memiliki dua indikator yang harus diperhatikan yaitu rasa puas atas produk dan layanan yang ada dan perasaan keseluruhan.

\subsection{Pengaruh Servicescape dan Kepuasan Pelanggan}

Servicescape dan kepuasan pelanggan memiliki hubungan yang erat, karena persepsi konsumen akan sebuah kepuasan sangat dipengaruhi oleh sebuah konsep servicescape. McDonell dan Hall (2008) "The servicescape is physical setting within which service occurs and which influences customer's perceptions of the servicescape (perceived quality) and the subquent internal (i.e degree of satisfaction) and external (i.e behavior with respect to patronage an purchase) response". Dalam artian bahwa sebuah pengaturan lingkungan fisik atau fasilitas yang terjadi dalam layanan dan yang mempengaruhi persepsi konsumen dalam servicescape adalah kualitas yang dirasakan langsung oleh konsumen baru yang selanjutnya adalah dalam internal konsumen atau tingkat kepuasan, juga eksternal atau perilaku yang berhubungan dengan sebuah respon pembelian atau konsumsi. Konsep servicescape yang nyaman mampu mempengaruhi pikiran dan perasaan pelanggan yang pada akhinya menimbulkan kepuasan atas suasana yang mendukung di lingkungan sekitar. 


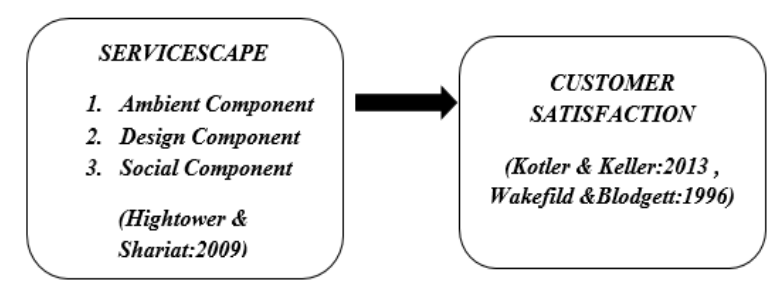

Gambar 2. Kerangka Pemikiran

Berdasarkan fenomena yang telah dipaparkan, maka hipotesis untuk penelitian ini adalah:

H0 : Tidak terdapat pengaruh positif yang signifikan servicescape terhadap kepuasan pelanggan.

Ha : Terdapat pengaruh positif yang signifikan servicescape terhadap kepuasan pelanggan.

\section{Metode Penelitian}

\subsection{Sampel}

Dalam penelitian ini, teknik sampling yang digunakan adalah teknik non-probility sampling dengan cara pengambilan sampel menggunakan purposive sampling. Sugiyono (2013) mendefinisikan bahwa non-probility sampling merupakan sebuah teknik pengambilan sampel yang tidak memberi kesempatan yang sama bagi setiap anggota populasi yang ada untuk dipilih menjadi sampel.

Untuk jumlah sampel dalam penelitian ini, peneliti menggunakan 100 orang responden. Jumlah minimum sebuah sampel dalam penelitian deskriptif menurut Wallen dan Fraenkel dalam Hermawan dan Amirulloh (2016) yaitu minimal sebanyak 100 responden. Untuk menghindari kurangnya jumlah sampel yang dapat dianalisis, peneliti dapat menambah jumlah sampel dengan menggunakan rumus yang disarankan oleh Wanrich dan Lininger dalam Dantes (2012) sehingga jumlah sampel yang digunakan dalam penelitian ini yaitu berjumlah 117 responden.

\subsection{Uji Validitas dan Reliabilitas}

Sugiyono (2013) mengemukakan bahwa validitas merupakan tingkat keandalan dan kesahihan sebuah alat ukur yang digunakan. Jika instrumen yang digunakan dalam penelitian dikatakan valid, maka alat ukur tersebut sudah dapat digunakan untuk mengukur apa yang seharusnya diukur. Pada penelitian ini, uji validitas pra penelitian untuk instrumen yang digunakan dilakukan kepada sebanyak 30 dan 117 orang responden. Kriteria dalam menentukan sebuah kuesioner valid atau tidak adalah sebagai berikut: Jika $r$ hitung $>r$ tabel maka pertanyaan tersebut valid.

Jika $r$ hitung $<\mathrm{r}$ tabel maka pertanyaan tersebut tidak valid.

Sebuah kuesioner atau alat ukur akan dikatakan reliable atau handal menurut Ghozali (2013) apabila jawaban responden akan pernyataan adalah konsisten atau stabil. Uji reliabilitas ini akan dilakukan setelah melakukan uji validitas dengan hasil yang valid. Menurut Noor (2014) reliabilitas suatu penelitian dapat diketahui melalui sejauh mana skor hasil pengukuran dapat dipercaya dari kekeliruan pengukuran (measurement error) dengan teknik yang paling umum digunakan yaitu Alpha Cronbach. Nilai Alpha yang menunjukkan > 0,60 disebut reliabel.

\subsection{Analisis Statistik Deskriptif}

Analisis statistik deskriptif dapat memperlihatkan nilai minimum, nilai maksimum, nilai tengah, ratarata, dan standar deviasi dari variabel servicescape (X) dan juga variabel kepuasan pelanggan (Y). Dalam penelitian ini skor maksimum yang digunakan adalah lima dan skor minimumnya adalah satu, maka intervalnya adalah: 0,8. maka dapat dibuat sebuah batasan kriteria untuk variabel servicescape dan kepuasan pelanggan, yang dapat dilahat pada tabel 2 . 
Tabel 2. Interpretasi Nilai Hasil Analisis Deskriptif

\begin{tabular}{|c|c|}
\hline Kriteria & Interpretasi \\
\hline $1.00-1.79$ & Sangat rendah/buruk \\
\hline $1.80-2.59$ & Rendah/buruk \\
\hline $2.60-3.39$ & Cukup tinggi/baik \\
\hline $3.40-4.19$ & Tinggi/baik \\
\hline $4.20-5.00$ & Sangat Tinggi/baik \\
\hline
\end{tabular}

\subsection{Analisis Korelasi dan Uji Regresi Linear}

Analisis korelasi yang sederhana menggambarkan hubungan antara variabel dua variabel. Menurut Sugiyono (2013) analisis korelasi digunakan untuk mengukur besarnya hubungan antara kelompok nilai variabel $\mathrm{X}$ dengan kelompok nilai variabel $\mathrm{Y}$.

Regresi atau peramalan merupakan suatu proses memperkirakan secara sistematis mengenai apa yang paling memungkinkan terjadi di masa yang akan datang berdasarkan informasi masa lalu dan sekarang agar kesalahan dapat di minimalisir. Analisis regresi linier sederhana digunakan untuk menganalisis pengaruh variabel servicescape terhadap kepuasan pelanggan. Berikut ini adalah rumus dari regresi linier sederhana $Y=a+b . X$.

Koefisien determinasi ini berfungsi untuk mengetahui persentase besarnya pengaruh variabel terikat dan juga variabel bebas. Menurut Ghozali (2013), koefisien determinasi utamanya merupakan cara untuk mengukur seberapa jauh kemampuan model dalam menerangkan variasi variabel dependen. Nilai koefisien determinasi itu dapar berkisar antara $0(0 \%)<\mathrm{R} 2<1(100 \%)$. Artinya, nilai R2 yang kecil mencerminkan kemampuan variabel-variabel independen dalam menjelaskan variasi variabel dependent amat terbatas. Semakin kuat koefisien korelasi maka akan semakin besar pula koefisien determinasi, begitu juga sebaliknya.

\section{Hasil dan Pembahasan}

Responden dalam penelitian ini yaitu sebanyak 117 orang yang terdiri dari 54 orang laki-laki dan 63 orang perempuan. Usia responden yang terbanyak dalam penelitian ini yaitu berusia 21 sampai 25 tahun. Karakeristik responden yang terbanyak berdasarkan pekerjaan yaitu sebagai karyawan. Rata-rata responden berkunjung sebanyak 2 sampai 3 kali dalam satu bulan dan responden terbanyak yang berpenghasilan sebesar Rp. 501.000 sampai dengan Rp. 1.000.000.-.

\subsection{Uji Validitas dan Reliabilitas}

Bersumber pada hasil uji validitas yang telah dilakukan pada 30 orang responden untuk variabel servicescape, semua instrumen dapat dinyatakan valid karena nilai yang ada pada kolom Corrected Item-Total Correlation $\geq 0.3061$. Berikut adalah uji validitas variabel servicescape yang dilakukan kepada 117 orang responden. Berdasarkan hasil uji validitas yang dilakukan kepada sebanyak 117 orang responden untuk variabel kepuasan pelanggan, seluruh instrumen penelitian dinyatakan valid dikarenakan nilai yang ada pada kolom Corrected Item-Total Correlation $\geq 0.1528$.

Tabel 3 Hasil Uji Validitas Servicescape

\begin{tabular}{|c|c|c|c|}
\hline & Corrected Item-Total Correlation & Cronbach's Alpha if Item Deleted & R Tabel \\
\hline ac1 & 0,572 & 0,917 & 0,1528 \\
\hline ac2 & 0,598 & 0,916 & \\
\hline ac3 & 0,527 & 0,918 \\
\hline ac4 & 0,592 & 0,916 \\
\hline ac5 & 0,514 & 0,918 \\
\hline ac6 & 0,542 & 0,917 & \\
\hline dc1 & 0,607 & 0,916 & \\
\hline dc2 & 0,642 & 0,916 & \\
\hline dc3 & 0,590 & 0,916 & \\
\hline
\end{tabular}




\begin{tabular}{|l|l|l|}
\hline $\mathrm{dc} 4$ & 0,482 & 0,919 \\
\hline $\mathrm{dc5}$ & 0,508 & 0,919 \\
\hline $\mathrm{dc} 6$ & 0,604 & 0,916 \\
\hline $\mathrm{dc7}$ & 0,505 & 0,918 \\
\hline $\mathrm{dc} 8$ & 0,581 & 0,917 \\
\hline $\mathrm{dc} 9$ & 0,601 & 0,916 \\
\hline $\mathrm{sc} 1$ & 0,535 & 0,918 \\
\hline $\mathrm{sc} 2$ & 0,649 & 0,916 \\
\hline $\mathrm{sc} 3$ & 0,634 & 0,916 \\
\hline $\mathrm{sc} 4$ & 0,724 & 0,914 \\
\hline $\mathrm{sc5}$ & 0,537 & 0,918 \\
\hline $\mathrm{sc6}$ & 0,551 & 0,918 \\
\hline
\end{tabular}

Untuk variabel kepuasan palanggan, uji validitas yang dilakukan kepada 30 orang responden menunjukkan bahwa nilai pada kolom Corrected Item-Total Correlation $\geq 0.3061$. Hal tersebut juga terbukti pada uji validitas yang dilakukan kepada 117 orang responden. Berdasarkan hasil uji validitas yang dilakukan terhadap variabel kepuasan pelanggan dengan total responden sebanyak 117 orang, seluruh instrumen dari variabel ini dinyatakan valid karena nilai yang ada pada kolom Corrected ItemTotal Correlation $\geq 0.1528$. Berdasarkan pada tabel 5 diperoleh Cronbach's Alpha pada variabel servicescape yang dilakukan kepada sebanyak 30 orang responden maupun 117 orang responden yaitu $\geq 0.8$ yang artinya reliabilitas baik. Begitu juga dengan variabel kepuasan pelanggan, baik dengan jumlah responden sebanyak 30 orang dan juga 117 orang, hasil pengujian yang diperoleh yaitu di atas 0.8 yang artinya reliabilitas baik.

Tabel 4 Hasil Uji Validitas Kepuasan Pelanggan

\begin{tabular}{|c|c|c|c|}
\hline & Corrected Item-Total Correlation & Cronbach's Alpha if Item Deleted & R Tabel \\
\hline $\mathrm{cs} 1$ & 0,552 & 0,878 & \multirow[t]{9}{*}{0,1528} \\
\hline $\operatorname{cs} 2$ & 0,591 & 0,876 & \\
\hline $\operatorname{cs} 3$ & 0,645 & 0,871 & \\
\hline $\operatorname{cs} 4$ & 0,689 & 0,867 & \\
\hline $\operatorname{cs} 5$ & 0,598 & 0,875 & \\
\hline $\operatorname{cs} 6$ & 0,685 & 0,867 & \\
\hline cs7 & 0,661 & 0,869 & \\
\hline $\operatorname{cs} 8$ & 0,716 & 0,865 & \\
\hline $\operatorname{cs} 9$ & 0,580 & 0,876 & \\
\hline
\end{tabular}

Tabel 5 Hasil Uji Reliabilitas

\begin{tabular}{|c|c|c|c|}
\hline Variabel & $\boldsymbol{N}$ & Cronbach's Alpha & N of Items \\
\hline \multirow{2}{*}{ Servicescape } & 30 & 0,921 & 21 \\
\cline { 2 - 4 } & 114 & 0,921 & 21 \\
\hline \multirow{2}{*}{ Kepuasan Pelanggan } & 30 & 0,904 & 9 \\
\cline { 2 - 4 } & 114 & 0,884 & 9 \\
\hline
\end{tabular}

\subsection{Analisis Statistik Deskriptif}

Tabel 6 menunjukkan hasil statistik deskriptif dari variabel servicescape (X). Dapat diketahui dari tabel tersebut nilai terendah dari 117 jawaban yang diberikan responden untuk variabel servicescape adalah bernilai 2 dan jawaban tertinggi atau nilai maksimumnya adalah 5. Mean atau nilai rata-rata dari variabel servicescape ini adalah sebesar 3.90 yang berada pada interval 3,40-4,19 yang memiliki arti 
bahwa variabel servicescape ada pada kategori baik. Hal tersebut didukung oleh pernyataan responden yang ditunjukkan dengan nilai standar deviasi yang nilainya kurang dari $20 \%$ dari mean yaitu sebesar 19,56\%. Nilai tersebut menunjukkan bahwa jawaban yang diberikan oleh sebanyak 117 orang responden untuk variabel servicescape ini kurang bervariasi atau relatif sama. Dalam variabel servicescape dimensi social component memiliki nilai mean terendah yaitu sebesar 3,83 yang masih dalam kategori baik. Sedangkan dimensi dengan nilai mean tertinggi yaitu dimensi ambient component dengan nilai sebesar 4.01.

Tabel 6 Hasil Analisis Deskriptif Variabel Servicescape

\begin{tabular}{|l|c|c|c|c|c|}
\hline \multicolumn{1}{|c|}{ Dimensi } & $\boldsymbol{N}$ & Min & Max & Mean & Std Dev \\
\hline Ambient Comp & 117 & 2 & 5 & 4,01 & 0,753 \\
\hline Design Comp & 117 & 2 & 5 & 3,88 & 0,770 \\
\hline Social Comp & 117 & 2 & 5 & 3,83 & 0,763 \\
\hline Variabel Servicescape & 117 & 2 & 5 & 3,90 & 0,763 \\
\hline Valid N (listwise) & 117 & & & & \\
\hline
\end{tabular}

Dalam dimensi ambient component terdapat beberapa indikator yang membentuknya. Ada satu indikator yang menjadi indikator terendah akan tetapi masih dalam kategori tinggi, yaitu indikator pencahayaan. Berdasarkan hasil pengamatan peneliti di lapangan, memang pencahayaan yang ada di Eduplex Bandung tidak merata. Tidak semua sudut atau bagian yang ada di Eduplex Bandung memiliki pencahayaan yang baik. Tempat yang memiliki pencahayaan yang kurang baik dari sorot lampu yang ada maupun cahaya langsung dari paparan sinar matahari langsung tidak banyak yang ditempati oleh konsumen. Cahaya yang kurang sangat terlihat dari penggunaan warna lampu yang berwarna kuring ditambah dengan dinding yang berwarna gelap. Hal tersebut mengindikasikan bahwa sebagian besar pelanggan Eduplex Bandung merasa kurang nyaman dengan beberapa pencahayaan yang.

Dalam dimensi social component terdapat dua indikator yaitu karyawan dan konsumen. Karyawan merupakan pengantar jasa yang secara langsung berhubungan dengan konsumen. Karyawan juga termasuk jasa itu sendiri yang artinya adalah bahwa karyawan cerminan dari perusahaan itu sendiri (Lovelock, Wirtz dan Mussry : 2011). Dari kuesioner yang diberikan kepada konsumen, sebagian besar menjawab bahwa karyawan yang ada sudah cukup membantu konsumen jika sedang memerlukan bantuan. Akan tetapi, konsumen harus menunggu beberapa waktu agar karyawan mendatangi konsumen yang sedang membutuhkan. Hal tersebut dikeluhkan oleh beberapa orang konsumen yang ada di Eduplex Bandung. Kemudian konsumen, konsumen disini mendefinisikan bahwa konsumen lain bersikap ramah terlebih jika konsumen lainnya sedang membutuhkan bantuan. Indikator konsumen ini juga memiliki arti untuk menilai rasa nyaman konsumen itu sendiri. Konsumen akan memiliki hubungan yang baik dengan konsumen yang lain apabila di stimulasi oleh sikap ramah karyawan.

Menurut Tombs dan Kennedy (2003:454) dimasukkannya pelanggan sebagai bagian dari servicescape sangat penting, mengingat bahwa layanan berhubungan langsung dengan pelanggan. Pelanggan dapat melihat dan menilai bagaimana perilaku sosial pelanggan lain atas layanan yang diberikan. Berdasarkan pembahasan di atas, dapat disimpulkan bahwa ketiga dimensi yang membentuk variabel servicescape telah memiliki nilai yang baik di Eduplex Bandung. Mulai dari dimensi ambient component yang baik, yang kemudian diikuti oleh dimensi design component yang juga ada dalam kategori baik, serta dimensi social component yang merupakan dimesni dengan nilai rata-rata terendah akan tetapi masih dalam kategori baik.

Tabel 7. Hasil Analisis Deskriptif Variabel Kepuasan Pelanggan

\begin{tabular}{|l|c|c|c|c|c|}
\hline \multicolumn{1}{|c|}{ Dimensi } & $\boldsymbol{N}$ & Min & Max & Mean & Std.Dev \\
\hline Rasa puas atas produk dan layanan yang ada & 117 & 2 & 5 & 3,82 & 0,717 \\
\hline Perasaan keseluruhan & 117 & 2 & 5 & 3,84 & 0,672 \\
\hline Dimensi Kepuasan Pelanggan & 117 & 2 & 5 & 3,82 & 0,702 \\
\hline Valid N (listwise) & 117 & & & & \\
\hline
\end{tabular}


Variabel kepuasan pelanggan memiliki jawaban atas pertanyaan terendah yaitu 2 dan jawaban tertinggi bernilai 5. Tabel 4.10 menunjukkan bahwa nilai rata-rata variabel kepuasan pelanggan memiliki nilai sebesar 3,82. Merujuk pada Tabel 3.3 yang ada pada laporan penelitian ini, nilai tersebut berada pada interval 3,40 - 4,19 yang artinya tinggi. Standar deviasi variabel kepuasan pelanggan menunjukkan angka 0,702 atau sama dengan $18,35 \%$ dari nilai mean, artinya standar deviasi dari kepuasan pelanggan tidak lebih dari $20 \%$ nilai mean-nya dan menunjukkan bahwa respon memberikan jawaban untuk variabel ini relatif sama atau dengan kata lain variasi jawaban yang diberikan responden cukup kecil dan tidak bervariasi. Variabel kepuasan pelanggan memiliki dua indikator yang membentuknya yaitu rasa puas atas produk dan layanan yang ada dengan nilai rata-rata sebesar 3,84 yang artinya adalah baik. Hal ini mengindikasikan bahwa konsumen Eduplex Bandung nemempatkan Eduplex Bandung menjadi tujuan yang dipilih secara berulang dan teratur karena merasa puas atas produk dan layanan yang ada. Indikator ini menjadi penting dalam meningkatkan kepuasan konsumen. Untuk dapat menciptakan rasa puas atas produk dan layanan yang ada terdapat empat faktor utama yang harus diperhatikan oleh perusahaan atau manajemen seperti yang dikatakan oleh Lupiyoadi (2008). Faktor yang pertama adalah kualitas produk. Konsumen akan merasa puas apabila hasil evaluasi mereka menunjukkan bahwa produk yang mereka gunakan berkualitas. Selanjutnya adalah faktor kualitas pelayanan. Untuk seluruh sektor industri khususnya industri jasa, kualitas pelayan sangatlah harus diperhatikan karena konsumen akan merasa puas bila mereka mendapatkan pelayanan yang baik yang sesuai dengan harapan. Faktor ketiga adalah faktor emosional. Konsumen akan merasa bangga dan mendapatkan keyakinan bahwa orang lain akan kagum terhadapnya bila menggunakan produk dengan merek tertentu yang cenderung mempunyai tingkat kepuasan yang lebih tinggi. Kepuasan yang diperoleh bukan karena kualitas dari produk tersebut akan tetapi dari nilai sosial yang membuat konsumen menjadi puas terhadap merek tertentu. Faktor yang terakhir yaitu faktor harga. Produk yang memiliki kualitas yang relatif sama dan memiliki harga yang lebih murah akan diberikan nilai yang lebih tinggi oleh konsumen atau dengan kata lain, konsumen akan berani membayar lebih jika sudah mengetahui kualitas produk yang dihasilkan.

Indikator yang kedua adalah perasaan keseluruhan yang dirasakan oleh pelanggan yang memiliki nilai rata-rata sebesar 3,84. Hal ini mengindikasikan bahwa perasaan keseluruhan konsumen Eduplex Bandung, merasa senang ketika berada di Eduplex Bandung selain dari rasa puas yang diterima atas produk dan pelayanan yang ada. Menurut Wakefield \& Blodgett (1996) tanggapan positif akan menghasilkan perilaku pendekatan yang juga harus menjadi pertimbangan mendasar bagi manajemen, karena dalam sebagian besar pengaturan layanan, semakin lama seseorang tinggal di fasilitas, semakin banyak uang yang dibelanjakan.

\subsection{Uji Korelasi Sederhana}

Hasil dari signifikansi yang telah dilakukan bernilai 0,000 atau kurang dari 0,05 maka dapat disimpulkan bahwa terdapat hubungan yang signifikan antara servicescape dengan kepuasan pelanggan. Tabel 8 menunjukkan bahwa nilai korelasi antara variabel servicescape dengan variabel kepuasan pelanggan adalah sebesar 0,750. Merujuk pada interpretasi nilai korelasi menurut Bungin (2010:184), maka nilai korelasi sebesar 0,750 termasuk kedalam interval 0,70 ke atas, yang artinya adalah terdapat hubungan positif yang sangat kuat (very strong) antara variabel servicescape dengan variabel kepuasan pelanggan. Hasil dari nilai korelasi Pearson di atas menunjukkan nilai yang positif, maka hubungan antara servicescape dan kepuasan pelanggan adalah satu arah, yang memiliki arti jika servicescape meningkat maka kepuasan konsumen juga akan ikut meningkat.

Tabel 8. Hasil Uji Korelasi Sederhana

\begin{tabular}{|l|l|l|l|}
\hline \multicolumn{2}{|c|}{ Servicescape } & Customer Satisfaction \\
\hline \multirow{4}{*}{ Servicescape } & Pearson Correlation & 1 & $0,750^{* *}$ \\
\cline { 2 - 4 } & Sig. (2-tailed) & & 0,000 \\
\cline { 2 - 4 } & $\mathrm{N}$ & 117 & 117 \\
\hline \multirow{2}{*}{$\begin{array}{c}\text { Customer } \\
\text { Satisfaction }\end{array}$} & Pearson Correlation & $0,750^{* *}$ & 1 \\
\cline { 2 - 4 } & Sig. (2-tailed) & 0,000 & \\
\cline { 2 - 4 } & $\mathrm{N}$ & 117 & 117 \\
\hline
\end{tabular}




\subsection{Analisis Regresi Linear Sederhana}

Dapat diketahui dari tabel 9 bahwa nilai konstanta (a) 6,384 dengan koefisien regresi (b) sebesar 0,342. Maka dari hasil tersebut dapat diperoleh model regresi linear sederhana seperti di bawah ini:

$$
\begin{gathered}
Y=a+b X \\
Y=6,384+0,342 X
\end{gathered}
$$

Nilai a dan b pada persamaan regresi linear sederhana tersebut dapat diinterpretasikan sebagai berikut :

a. Konstanta sebesar 6,384 memiliki arti, jika servicescape sama dengan $(\mathrm{X}=0)$ atau tidak ada servicescape, maka kepuasan pelanggan hanya sebesar 6,384.

b. Servicescape memiliki nilai koefisien regresi linear sederhana sebesar 0,342. Hal tersebut memiliki arti bahwa apabila servicescape mengalami kenaikan satu-satuan maka kepuasan pelanggan akan mengalami peningkatan sebesar 0,342 satuan.

\begin{tabular}{|c|c|c|c|c|c|}
\hline \multirow{2}{*}{ Model } & \multicolumn{2}{|c|}{ Unstandard Coef. } & Standardized Coef. & $\mathbf{T}$ & Sig. \\
\hline & B & Std. Error & Beta & & \\
\hline 1 (Constant) & 6,384 & 2,322 & & 2,750 & 0,007 \\
\hline Servicescape & 0,342 & 0,028 & 0,750 & 12,165 & 0,000 \\
\hline
\end{tabular}

Tabel 9. Hasil Uji Regresi Linear Sederhana

\subsection{Koefisien Determinasi}

Koefisien determinasi juga digunakan untuk dapat menjawab rumusan masalah ketiga perihal seberapa besar pengaruh servicescape terhadap kepuasan pelanggan di Eduplex Bandung. Merujuk pada tabel 10, diperoleh angka R Square atau angka korelasi dikuadratkan $0,750^{2}$ yaitu sebesar 0,563. Angka tersebut disebut juga sebagai koefisien determinasi , maka besarnya koefisien determinasi dalam penelitian ini yaitu sebesar 0,563 atau sama dengan 56,3\%. Besaran nilai tersebut menunjukkan bahwa servicescape berpengaruh sebesar 56,3\% terhadap kepuasan pelanggan. Sedangkan sisanya yaitu sebesar $47,3 \%$ dipengaruhi oleh faktor-faktor lain yang tidak diteliti dalam penelitian ini.

Tabel 10. Koefisien Determinasi

\begin{tabular}{|c|c|r|r|r|}
\hline Model & \multicolumn{1}{|c|}{$\mathbf{R}$} & \multicolumn{1}{c|}{ R Square } & Adjusted R Square & Std. Error of the Estimate \\
\hline 1 & $0,750^{\mathrm{a}}$ & 0,563 & 0,559 & 3,031 \\
\hline
\end{tabular}

\subsection{Hasil Uji Hipotesis}

Berdasarkan hasil penelitian, servicescape yang ada di Eduplex Bandung berpengaruh positif signifikan terhadap kepuasan pelanggan. Hal tersebut dapat dibuktikan dengan hasil nilai $F_{0} \geq F_{1}$ yaitu 147,991 $\geq$ 3,92. Berdasarkan hasil perhitungan, nilai $\mathrm{t}$ hitung $\geq \mathrm{t}$ tabel yaitu $12,165 \geq 1,98081$. Merujuk pada interpretasi hasil uji statistik $t$ menurut Priyatno (2013:114), jika kriteria $F_{0} \geq F_{1}$, dengan taraf signifikansi sebesar 0,05 atau 5\% maka dapat diartikan bahwa $\mathrm{H}_{0}$ ditolak dan $\mathrm{H}_{\mathrm{a}}$ diterima. Hal tersebut menunjukkan bahwa servicescape berpengaruh secara signifikan terhadap kepuasan pelanggan di Eduplex Bandung.

\section{Kesimpulan dan Saran}

\subsection{Kesimpulan}

Dari hasil dari pengumpulan data, pengolahan data, dan analisis yang telah dilakukan, maka penulis dapat menarik kesimpulan yan menjawab perumusan masalah dari penelitian ini, sebagai berikut:

1. Servicescape yang ada di Eduplex Bandung berada pada kategori baik. Berdasarkan hasil pembahasan, dimensi ambient component berada pada kategori baik, diikuti dengan dimensi design component yang baik, dan juga dimensi social component yang masih dalam kategori baik. Dapat diartikan bahwa konsumen Eduplex Bandung menyukai servicescape yang ada. 
2. Kepuasan pelanggan di Eduplex Bandung berapa pada kategori tinggi. Indikator perasaan keseluruhan konsumen yang berada pada kategori paling tinggi. Dibawahnya yaitu indikator rasa puas atas produk dan layanan yang ada di Eduplex Bandung yang masih berada pada kategori tinggi. Dapat diartikan bahwa konsumen Eduplex Bandung merasakan kepuasan atas servicescape.

3. Besarnya pengaruh servicescape terhadap kepuasan pelanggan di Eduplex Bandung adalah sebesar $56,3 \%$. Sedangkan sisanya yaitu sebesar $47,3 \%$ dipengaruhi oleh faktor-faktor lain yang tidak diteliti dalam penelitian ini.

\subsection{Saran}

Berdasarkan hasil penelitian, walaupun tingkat servicescape yang ada di Eduplex Bandung sudah baik sehingga menimbulkan kepuasan pelanggan, Eduplex Bandung harus selalu melakukan perbaikan. Oleh karena itu, ada beberapa saran yang berhubungan dengan penelitian yang dilakukan, antara lain sebagai berikut:

1. Perbaikan pada dimensi social component yaitu dalam sisi karyawan itu sendiri. Sebaiknya karyawan dapat meningkatkan kinerjanya lebih baik lagi. Seperti sikap karyawan yang suka menolong, dan memberikan pelayanan dengan sikap lebih ramah. Jika karyawan mampu meningkatkan kinerjanya, maka dapat menstimulasi konsumen untuk berhubungan baik dengan konsumen yang lain dengan sikap yang bersahabat.

2. Pada beberapa tempat, pencahayaan dirasa kurang. Hal tersebut terjadi pada bagian yang berada di bagian ujung ruangan atau bangunan yang memiliki latar belakang warna yang gelap ditambah dengan warna lampu yang berwarna kuning, sehingga pencahayaan tersebut dirasa kurang atau gelap dan tidak ditempati oleh konsumen karena merasa kurang nyaman. Sebaiknya manajemen atau Eduplex dapat mengganti warna lampu dengan yang lebih terang dan berwarna putih agar tempat terlihat lebih terang.

3. Pelayanan yang diberikan oleh karyawan Eduplex Bandung sudah baik, akan tetapi harus lebih ditingkatkan. Sebaiknya karyawan ditempatkan di posisi yang mudah terlihat oleh konsumen sehingga dapat memaksimalkan pelayanan yang diberikan.

\section{Daftar Pustaka}

Bitner, M. (1992). Servicescape: the impact of physical surroundings on customer and employees. Journal of Marketing, 56(2), 57-67.

Bungin, B. (2010). Penelitian Kualitatif : Komunikasi, Ekonomi, KebijakanPublik dan Ilmu Sosial lainnya. Jakarta : Kencana Prenama Media Group.

Dantes, N. (2012). Metodologi Penelitian. Yogyakarta: Andi.

Ghozali, I. (2013). Aplikasi Analisis Multivariat dengan Program SPSS Edisi Ketujuh. Semarang: Badan Penerbit Universitas Diponegoro.

Hermawan, S. \& Amirullah. (2016). Metode Penelitian Bisnis Pendekatan Kuantitaif dan Kualitatif. Malang: Media Nusa Creative.

Hightower Jr, R., \& Shariat, M. (2009). Servicescapes Hierarchial Factor Structure Model. Global Review of Business and Economic Research, 5(2), 375-398.

Kotler, P. \& Keller, M. (2009). Manajemen Pemasaran Jilid 2, Edisi ketiga belas. Terjemahan Bob Sabran. Jakarta: Erlangga.

Lovelock, W. \& Mussry. (2012). Pemasaran Jasa Manusia, Teknologi, Strategi: Perspektif Indonesia. Jakarta: Erlangga.

McDonell, R. \& Hall, P. (2008). A framework for the evaluation of winery servicescapes: A New Zealand case. PASOS Revista de Turismo y Patrimonio Cultural, 6(2), 231-247.

Noor, J. (2014). Metode Penelitian. Jakarta: Kencana.

Priyatno, D. (2013). Mandiri Belajar Data dengan SPSS. Yogyakarta: Graha Ilmu.

Sugiyono. (2013). Metode Penelitian Pendidikan Pendekatan Kuantitatif, Kualitatif, dan R\&D. Bandung: Alfabeta.

Tjiptono, F. \& Diana, A. (2015). Pelanggan Puas? Tak Cukup!. Yogyakarta: Andi.

Tombs, M. \& Kennedy, R. (2002). Social Servicescape Conceptual Model. Marketing Theory Article 3(4), 447-475 
Wakefield, K. L. \& Blodgett, J. G. (1996). The Effect of The Servicescape on Customers' Behavioral Intentions in Leisure Service Setting. Journal of Services Marketing, 10(6), 45-61.

Zeithaml, V. A., Berry, L. \& Parasuraman, P. (1993). The nature and determinants of customer expectations of service. Journal of the Academy of Marketing Science, 21(1), 1-12.

\section{*Email korespondensi:}

azmimutiaainun@gmail.com 